\title{
POSSIBILITIES OF BINDING ORGANIC MOLECULES WITHIN THE ENAMEL CRYSTAL STRUCTURE IN DOGS \\ TIHAČEK-ŠOJIĆ LJILJANA
}

Faculty of Stomatology, Belgrade

(Received 1. May 2004)

The main objective of this paper is to determine the possibilites of binding organic molecules to the enamel crystal structure.

The experimental study in vivo was performed on maxillar molars in dogs. Time in vivo was 12 months, after which animals were executed. All intact teeth were extracted and the study of the enamel crystal structure was continued in vitro.

After treating the enamel tissue with the solution of organic spin marker 4-Amino-Tempo, the follow-up of the changes of values of the apatite crystal unit cell parameters was done by X-ray diffraction.

The following conclusions may be reached after evaluation of the obtained results: in addition to the process of diffusion throught the interprysmatic space of the enamel tissue, the organic molecules also play a crucial role in the changes of the crystal grid size, due to binding of organic parts of molecules in the enamel crystal structure. Permanent oscillations of the existing oxygen bonds in the enamel crystal structure have been determined every few weeks and depend on the process of substitution and resubstitution of $\mathrm{OH}$ ions by ions from organic and inorganic molecules and various dental materials.

The local application of the fluorine based preparations on permanent teeth must be repeated every two months due to breakedown of oxygen bond and resubstitution.

Key words: X-ray diffraction, substitution, resubstitution, enamel tissue, unit cell parameters.

\section{INTRODUCTION}

The main elements of the inorganic component of the enamel tissue are found in the form of apatite crystals. The apatite crystals are hexagonally shaped, with an average size of $160 \times 40 \times 25 \mathrm{~nm}$. The crystal size depends on the crystallization rate. The apatite crystals in the enamel prism are ten times greater, on the average, than the crystals in the dentine and bones, which is caused by a slower rate of development of the enamel tissue. Ferguson and Chesnut (1978) and Doi et al. (1980) state that biological enamel apatite, contrary to pure mineral forms of hydroxylapatite and fluorapatite, may show a small size and 
imperfections in the shape which hinders good analysis of the elementary cell parameters.

There is often a possibility of existence in the tested sample of the enamel tissue of several kinds of apatite, which Jansen and Visser (1985) determined by chemical analysis. The hydroxyl ion may be substituted by chlorine ion in chlorine apatite, with fluorine ion in fluorapatite and with carbonate ion in dentine (Arends ànd Christoffersen, 1986, Battistone et al., 1967, Bakhos et al., 1977, Baud, 1970 and Callens, 1986). Thus, Frank et al. (1960), Klein (1960) and Poole and Silverstone (1973) confirmed that an exchange is possible between the apatite ion and the surrounding environment. One third of the ions from the crystal grid may be substituted by ions which have diffused from the environment, whether it is a heteroionic or an isoionic substitution. With respect to substitution it should be noted that there is a greater chance for it on the crystal surface than with the atoms and groups in depth.

For the substitution of ions in the crystal grid of particular importance are:

- similarity in the size of ion radii,

- valence,

- high ion reactivity,

- perfection of the crystal shape,

- size of the apatite crystal and

- value of the diffusion coefficient of certain ions.

The similarity in the size of ion radii allows the chlorine $(0.188 \mathrm{~nm})$ and fluorine $(0.129 \mathrm{~nm})$ ions to be substituted by hydroxyl ions $(0.133 \mathrm{~nm})$. It is important to point out that the substitution of the hydroxyl ions by fluorine ions (heteroionic exchange) is the easiest, since both ions have the basic hydration number 5. This is of imprortance since the other halogen elements, whose ion radius size is similar to the hydroxyl ion, have the basic hydration number 2 . Heteroionic substitutions of the hydroxyl ion are also easy to achieve with ions of elements which are highly reactive with this ion and have an unpaired electron.

Elliott (1986), Eldredge et al. (1987), Frank et al. (1960) and Frazier (1968) stated that size and perfection of the shape of the apatite crystal are inversely proportional to the ion substitution ability.

The parameters of the crystal apatite unit cell, i.e. " $\alpha$ " and "c" axis, are crucial. It can be concluded on the basis of their sizes whether in the tested tooth enamel hydroxylapatite, chlorapatite, fluorapatite or some other form of apatite is present in a larger quantity. Through determination of the parameters of the hexagonally shaped crystal apatite unit cell it can be concluded whether the ion substitution took place from the solution whose diffusion is monitored.

The unit cell of the apatite structure has two axes (a-axis) of the same length under a $120^{\circ}\left(\gamma=120^{\circ}\right)$ angle and a third one (c-axis) under a right angle with respect to these two axes $\left(\alpha=\beta=90^{\circ}\right)$. The axis of the unit cell with apatite structure which is hexagonally shaped are equal between them, and the angles they form are $\alpha=\beta=90^{\circ}$ and $\gamma=120^{\circ}$.

The parameters of these cells are particularly important in the crystallographic research. According to Beevers the cell parameters in the 
hydroxylapatite crystal are: a-axis $=0,941 \mathrm{~nm}$ and c-axis $=0,688 \mathrm{~nm}$. In fluorapatite a-axis $=0,937 \mathrm{~nm}$ and e-axis $=0,688 \mathrm{~nm}$.

The changes of the apatite stucture are difficult to measure and therefore require the implementation of extremely accurate research methods, as stressed by Arwill et al. (1965), Funduk et al. (1986) and Katz et al. (1969). Until now only a few authors have investigated the changes on human teeth after treatment with various substances or dental materials.

The main objective of thise research is to investigate the possibilities of binding organic molecules to the crystal enamel structure.

\section{MATERIAL AND METHODS}

The size of the basic crystal cell can be measured by X-ray diffration.

Based on the changes in size of the basic enamel crystal cell it is possible to determine whether the binding of organic and inorganic molecules occured in the crystal grid structure.

The experimental study in vivo was performed on maxillar molars in dogs. Time in vivo is 12 months, after which the animals were sacrificed. All the intact teeth were extracted and the study was continued on the enamel crystal structure in vitro.

The extracted molars were divided into two experimental groups:

I - First group (control group): extracted molars whose surface of intact enamel was pulverized. The enamel tissue of these teeth was not treated by reagents.

II - Second group: molars that after extraction were placed into a water solution $(0.02335 \mathrm{M})$ of an organic spin marker 4-Amino-Tempo, at room temperature $\left(t=20^{\circ} \mathrm{C}\right)$. After a 12 month period the teeth were rinsed with distilled water, dried and their enamel tissue was pulverized.

The pulverisation of the enamel tissue was carried out in a mortar. Samples of pulverized enamel tissue were placed into tubes and delivered for crystallographic testing.

X-ray diffraction is based on the phenomenon that appears if the passage of $X$-rays through the crystal structure is in accordance to Bragg's rule.

In order to obtain data on X-ray diffraction the powder diffractometer is used.

An X-ray tube having an anode (anti cathode) made of copper is used as a radiation source. The wavelenght of the radiation specific for copper is $\lambda_{\text {cuK } \alpha}=$ $0.154178 \mathrm{~nm}$. As copper has two characteristic lines CuK $\alpha 1=0.154040 \mathrm{~nm}$ and CuK $\alpha 2=0.154434 \mathrm{~nm}$ of which the first is twice as intesive, the above given CuK $\alpha$ is obtained by the formula:

$$
\lambda_{\mathrm{CuK} \alpha}=\frac{2 \lambda_{\mathrm{CuK} \alpha 1}+\lambda_{\mathrm{CuK} \alpha 2}}{3}
$$

In order to perform the emission of specific radiation with an intensity sufficient for diffractometry, voltage $U_{a}$ of about $40 \mathrm{kV}$ is brough to the tube anode 
and a current $\mathrm{I}_{\mathrm{a}}$ of about $20 \mathrm{~mA}$ is passed. Such an X-ray generator often has a stabilized source of anode current. The beam of X-ray is led to the powder goniometer. The width of the X-ray beam is limited by crevices (S).

Such a collimated beam drops on the preparation $(P)$.

The preparation is made by pressing the powder of the test material in an aluminum frame the opening of which is $20 \times 10 \times 2 \mathrm{~mm}$.

This pulverized sample is placed in the center of the goniometer so that the upper surface of the testing powder is on the axis of the goniometer (O). The diffracted beam from the sample passes through the crevice and drops on the $X$ ray detector $(D)$. During the acquisition of diffraction data the detector moves at a constant rate around the axis, whereas the preparation moves at half the rate. The usual rate for the detector movement is $20 \mathrm{~min}$. Intensified and formed impulses are led from the X-ray detector to the integrator which serves to present the number of impulses in the unittime as voltage values. A recorder registers the changes in voltage on a paper strip. The paper strip moves at a constant rate synchronous with the movement of the detector on the goniometer so that the abscissa diagram makes an angle of $20^{\circ}$ and on the ordinate is the intensity of the diffracted ray, namely the number of impulses per second.

One diffractogram is composed of the basic line (phon or background) for the time when there had been no diffraction and peaks of different heights, with different angles $2 \theta$, of which each represents one family of grid planes whose position in space is indexed by Miller indices (hkl). The intensity 1 and angles $2 \theta$ are to be determined from each diffractogram. The reflection intensity is determined in units $1 / 100$ of the heigh of the peak the highest intensity on the diagram. This way all other values have an intensity less than 100.

The diffraction angle values are measured by lowering the normal on the abscissa from the middle of the peak measured at half of its height. According to the equation:

$$
d=\frac{\lambda}{2 \sin \theta}
$$

where

$\mathrm{d}$ - equal distance of grid planes of Miller indices (hkl)

$\lambda$ - wavelength of $X$-ray radiation and

$\theta$-angle formed by the X-ray with a family of parallel planes, if assumed that $n=1$, the interlayer distances are calculated for all reflections.

The X-ray of both groups of samples were filmed on Philips diffractometer, type 1820, with a generator produced by the same company, type 1729. The operating voltage of the X-ray was $40 \mathrm{kV}$, and the current power of $30 \mathrm{~mA}$. The powder diagrams were recorded in a range from $4^{\circ}-130^{\circ}$.

Philips APD computerized system was used for data processing which automatically calculated the interlayer distance and determined the intensity. 


\section{RESULTS}

In both test groups sample diffractograms were made and their analysis and comparison was performed.

By the least square method the sizes of unit cells were caculated and reflections indexed using the LSUCR program.

The difference in the parameters of the elementary cells ( $a$ and $c$ axis) do not have to be a precise indication of true relationships of crystal dimensions. It may be that the different crystals of the enamel tissue have in one case a shorter and wider habitus, while in another case the habitus is narrower and more elongated. In such seeminly different crystals of the enamel tissue, the volumes of the elementary cells may be identical.

In order to determine with certainty the accuracy of the unit cell, using the existing angles and parameters, the volume of the enamel crystal unit cells was calculated according to the formula:

$$
\mathrm{V}=\mathrm{a}^{2} \cdot \mathrm{c} \cdot \cos 30^{\circ}
$$

where:

$\mathrm{V}$ - unit cell volume

a - a-axis of the unit cell,

$c-c$-axis of the unit cell.

In group I in the prepared samples a diffractogram was obtained (Figure 1).

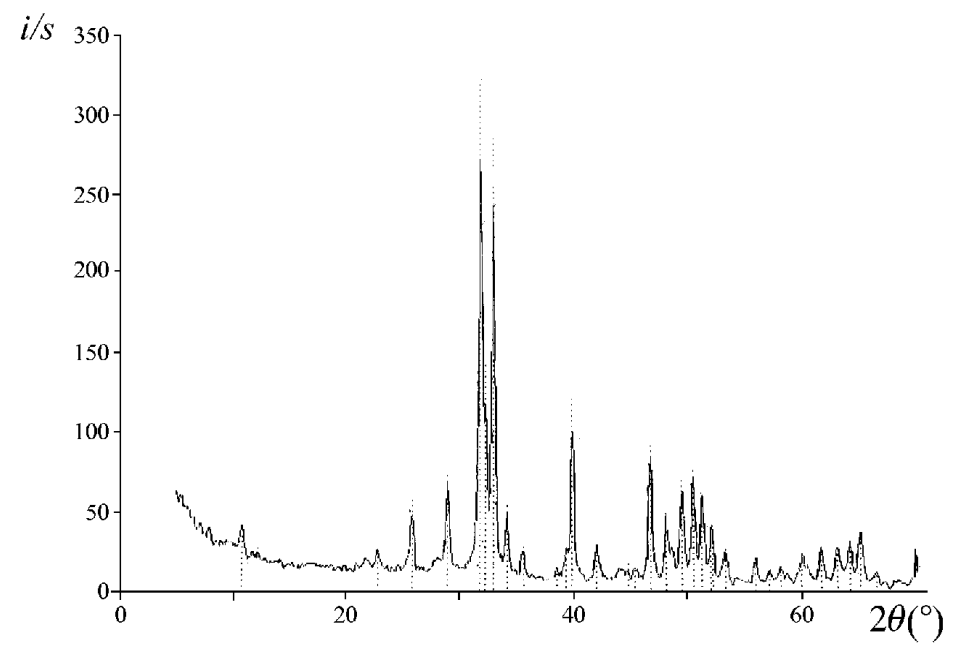

Figure 1. Diffractogram of the 1st group of preparations (native enamel tissue) 
This group represents a control group.

The values of unit cell parameters and the crystal elementary cell volume (V) of the native enamel tissue are presented in the Table 1.

Table 1. Parameters of the enamel tissue crystal elementary cell

\begin{tabular}{|c|c|}
\hline Parameters & $\begin{array}{c}\text { CONTROL GROUP } \\
\text { (enamel tissue) }\end{array}$ \\
\hline \hline$a$-axis $(\mathrm{nm})$ & $0.9438(2)$ \\
\hline$c$-axis $(\mathrm{nm})$ & $0.6890(1)$ \\
\hline Volume $V\left(\mathrm{~nm}^{3}\right)$ & $0.5315(3)$ \\
\hline
\end{tabular}

In order to determine the changes in the enamel tissue structure (changes of the elementary cell parameters) of the GROUP II, which has been treated with organic spin market 4-Amino-Tempo $(0.02335 \mathrm{M})$ an analysis of the obtained diffractogram was performed (Figure 2).

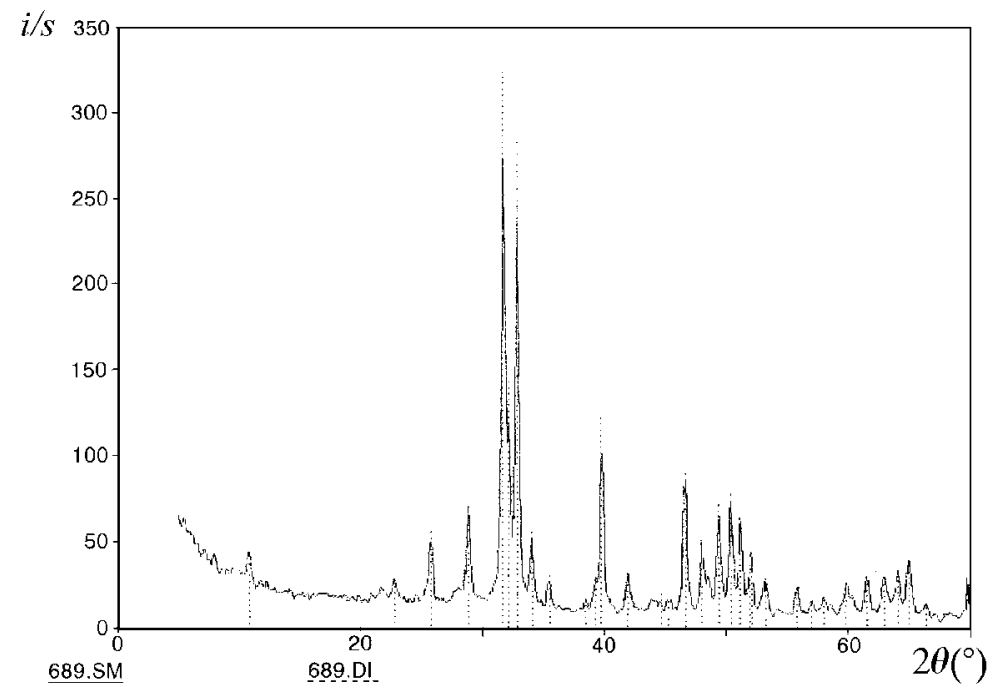

Figure 2. Diffractogram of the 2 nd group of preparations (enamel tissue treated by organic spin marker 4-Amino-Tempo)

At first glance a great similarity was observed in the quality of reflection of the control and treated group, however, by calculating the value of the reflection width it was concluded that the crystal grid parameters are not identical (Table 2).

The difference in the parameters is reflected in the increase of the $\alpha$-axis value by $0.0002 \mathrm{~nm}(\Delta \mathrm{a} / \mathrm{a}=0.02 \%)$, whereas the values of $\mathrm{c}$-axis did not change. 
The elementary cell value in the second group is also increased and this increase amounts to $0.0002 \mathrm{~nm}^{3}(\Delta \mathrm{V} / \mathrm{V}=0.02 \%)$ with respect to the native enamel tissue.

Table 2. Parameters of the crystal elementary cell of the 1st qnd 2nd groups of preparations

\begin{tabular}{|c|c|c|c|}
\hline Parameters & $\begin{array}{c}\text { Control group } \\
\text { (enamel tissue) }\end{array}$ & $\begin{array}{c}\text { I group } \\
\text { (enamel tissue + tempo) }\end{array}$ & Diffrence \\
\hline \hline a-axis $(\mathrm{nm})$ & $0.9438(2)$ & $0.9440(3)$ & 0.0002 \\
\hline c-axis $(\mathrm{nm})$ & $0.6890(1)$ & $0.6890(2)$ & - \\
\hline Volume $\vee\left(\mathrm{nm}^{3}\right)$ & $0.5315(3)$ & $0.5317(4)$ & 0.0002 \\
\hline
\end{tabular}

\section{DISCUSSION}

The effect of the organic spin marker 4-Amino-Tempo on the enamel tissue crystal grid has been detected. It is not only evident during the process of diffusion through the interprysmatic space of the enamel tissue but also plays a crucial role in the changes of the crystal grid size Tihaček Šojić (1988).

The highly reactive nitrogen oxide radical, which has an unpaired electron in the organic spin marker 4-Amino-Tempo, is comprised in the molecule which has a stool-like structure and not a planar structure. In the diffusion of the marker molecule through the interprysmatic space of the enamel tissue the nitrogen oxide radical can be found in the immediate vicinity of $\mathrm{OH}$ ion on the outer layer of the crystal grid of hydroxylapatite, whereby their heteroionic substitution occurs (Nixon et al., 1966). Nitrogen oxide radical has a tendency of substitution with $\mathrm{OH}$ ions, due to its high reactivity and tendency to stabilize the unpaired electron (Nichol et al., 1973). The value of the radius of the $\mathrm{OH}$ ion is $0.133 \mathrm{~nm}$. In the nitrogen oxide radical the nitrogen ion $\left(\mathrm{N}^{3}+\right)$ has a valence +3 and an ion radius value of $0.016 \mathrm{~nm}$. The oxygen $\left(\mathrm{O}^{-}\right)$in this compound has a valence -1 (negative single-valence) and the value of the ion radius is $0.176 \mathrm{~nm}$, so that the value of the ion radius of the entire nitrogen oxide radical is $0.192 \mathrm{~nm}$.

During substitution the nitrogen oxide radical is bound by the oxygen bond in the apatite, as it occurs during the $\mathrm{OH}$ ion substitution by fluorine. The oxygen bond contributes to a better mutual link between the ions in the crystal grid. The relationship of the sizes of the $\mathrm{OH}$ and $\mathrm{NO}$ ion radius $(0.133 \mathrm{~nm}: 0.192 \mathrm{~nm})$ is reflected in the increase of the value of the $\alpha$-axis of the unit cell, whereas there is no change of the value of the c-axis. At the same time there is an increase of the volume of the apatite crystal elementary cell which was also proved by the crystallographic analysis Tihaček Šojić Lj. (2000).

By the process of organic spin marker diffusion with nitrogen oxide radical through the interprysmatic space of the enamel tissue permanent oscillations of the number of non-bound marker molecules were determined. These moleculs had already diffused and are located in the tissue. Such oscillations, based on the 
crystallographic analysis of the enamel tissue, may be explained by constant heteroionic substitutions of $\mathrm{OH}$ ions with nitrogen oxide radical and vice versa. This means that the oxygen bond of the nitrogen oxyde radical in the apatite (hydroxylapatite) is not so stable to represent a definite substitution in the crystal grid (Leinfeldar et al., 1995). The oxygen bond of the nitrogen oxide radical in the crystal grid lasts 5-6 weeks, after this period it becomes unstable and the molecule continues to diffuse through interprysmatic spaces, until the nitrogen oxide radical is again in the immediate vicinity of the $\mathrm{OH}$ ion of the outer surface of the hidroxyl apatite crystal grid (Lefkowitz and Bodecker 1993). This pertains to all oxygen bonds that appear after the substitution of ions in the apatite crystal. The stability of the oxygen bond to the fluorine ion in the fluorapatite crystal, also like any other oxygen bond after substitution it may last several weeks after which occurs a resubstitution (Leus 1969).

The substitution and rebsubstitution represent permanent subsequent changes in the enamel tissue. The time period of rebsubstitution is affected by the reactivity of new ions, increased ion concentration in the inner and outer environment of the enamel crystal, limited stability of the oxygen bond, size of ion radius of introduced ions and many other factors.

\section{CONCLUSION}

Organic molecules, beside the process of diffusion through interprysmatic space of the enamel tissue, play a decisive role also in the changes of size of the crystal grid due to binding of organic parts of molecules in the enamel crystal structure.

Permanent oscillations of existing of oxygen bonds in the enamel crystal structure are determined every few weeks and depend on the process of substitution and resubstitution of $\mathrm{OH}$ ion by ions from organic and inorganic molecules and different dental materials.

Local application of fluorine-based preparations with permanent teeth must be repeated every 2 months due to breaking of the oxygen bond and the process of resubstitution.

Address for correspondence:

Dr. Ljiljana Tihaček - Šojić

Clinic for Prosthodontics

Faculty of Stomatology, Univrsity of Belgrade

Rankeova br 4, 11000 Belgrade

Serbia \& Montenegro

\section{REFERENCES}

1. Arends J, Christoffersen J, 1986, The nature of early caries lesions in enamel, J Dent Res, 65, 1, 2-11.

2. Arwill T, Myrberg N, Soremark R, 1965, Penetration of radioactive isotopes through enamel and dentine, I Diffusion of $22 \mathrm{Na}$ in fresh and coagulated dental tissues, J Dent Res, 44, 6, 1299-303.

3. Battistone GC, Feldman MN, Reba RC, 1967, The manganese content of human enamel and dentine, Arch Oral Biol, 12, 112-5. 
4. Bakhos Y, Bruwold F, Asenden R, 1977, In vivo estimation of the permeability of surface human enamel, Arch Oral Biol, 22, 599-603.

5. Baud CA, 1970, Electron probe and X-ray diffraction microanalyses of human enamel treated in vitro by fluoride solution, Car Res, 4, 32-6.

6. Callens FJ, Matthys PFA, Verbeeck RMH, Martens LC, 1986, Contribution of the $\mathrm{CO}^{3-}$ and the $\mathrm{CO}_{2}$ radicals to the asymmetric esr ${ }^{3}$ signal near g-2 in human tooth enamel, Zobozdrav Vestn, 41 , Supl. 1, 79-97.

7. Doi Y, Aoba T, Moriwaki Y, Okazaki M, Takahashi J, 1980, Orientations of carbonate ions in human tooth enamel studied with use of the $\mathrm{CO}_{3}$ radical ions as probes, J Dent Res , 59, 1473-7.

8. Elliott JC, 1986, The Structure and function of hydroxyapatite, Zobozdrav Vestn, 41, Suppl. 1, 25-42.

9. Eldredge JB, Hunt RS, 1987, Effect of fluoridation on coronal and root caries in the elderly, J Dent Res, 66, (spec iss): 179, 584.

10. Ferguson S, Chesnut DB, 1978, A magnetic resonance spin label study of human dental enamel, Arh Oral Biol, 23, 85-90.

11. Frank MR, Sognnaes RF, Kern R, 1960, Calcification of dental tissues with special reference to enamel ultrastructure, V: Calcification in biological systems. Amer Ass Apv Sci, Washington, 163-202.

12. Frazier PD, 1968, Adult Human Enamel: An Electron Microscopic Study od Crystallite Size and Morphology, J Ultrastruct Res, 22, 1-11.

13. Funduk N, Lahajnar G, Miljković L, Skočajić S, Kydon DW, Schrener LJ et al, 1986, A comparative NMR study of proton groups in dentin of 20 and 50 years old donors, Zobozdrav Vestn, 41, suppl 1, 139-60.

14. Jansen MT, Visser JB, 1985, Permeable structures in normal enamel, J Dent Res, 29, 5, 622-31.

15. Katz S, Beck CW, Muhler CJ, 1969, Crystallographic evaluation of enamel from carious and noncarious teeth, $J$ Dent Res, 48, 1280-3.

16. Klein H, 1960, Physico-chemical studies on the structure of dental enamel, II. A quantitative method for determining relative differences in the permeability of the teeth, J Dent Res, 10, 447-50.

17. Leinfelder KF, Wisniewski JF, Isenberg BP, 1995: Clinical evaluation of Herculite (injectable/condensable) a light cured posterior composite resin. Five year report. Internal report on file, Kerr Manufacturing Company.

18. Lefkowitz W, Bodecker CF, 1993, Concerning the vitality of the calcified dental tissues in the permeability of enamel, Brit Dent $J, 23$.

19. Leus PA, 1969, Biophysical methods of influencing the permeabillyty of dental enamel, Stomatologia (Moskva), 48, 21-4.

20. Nixon GS, Livingston HD, Smith H, 1966, Estimation of manganese in human enamel by activation analysis, Arch Oral Biol, 11, 247-52.

21. Nichol T, Judd G, Ansell GS, 1973, A two-stage model for human enamel demineralization as determined by scanning electron microscope analysis. J Dent Res, 52, 487-93.

22. Poole DFG., Silverstone LM, 1973, Observations with Scanning elektron microscopy on trauma induced microcavities in human enamel, Arch Oral Biol, 14, 1323-9.

23 Ronnholm E, 1962, The amelogenesis of human teeth as revealed by electron microscopy, II. The Development of the Enamel Crystallites, J Ultrastruct Res, 6, 249-303.

24. Robinson C, 1971, Variation in composition of dental enamel within thin ground tooth sections, Caries Res, 5, 44.

25. Rolla G, 1988, On the role of calcium flouride in the cariostatic mechanism of fluoride, Acta Odontol Scand, 46, 341-5.

26. Tihaček Lj, Stamenković D, Filipović V, 1988, Mikroskopsko merenje debljine gleđi na aproksimalnim površinama zuba, SGS, 4, 261-71.

27. Tihaček - Šojić Lj, 2000, Stomatološka protetika - Namenski ispuni, Nauka. Beograd. 


\title{
ISPITIVANJE MOGUĆNOSTI VEZIVANJA ORGANSKIH MOLEKULA U STRUKTURI KRISTALA GLEĐNOG TKIVA PASA
}

\author{
TIHAČEK-ŠOJIĆ LJILJANA
}

\section{SADRŽAJ}

Osnovni cilj ovog rada je bio ispitivanje mogućnosti vezivanja organskih molekula u strukturi kristala gleđnog tkiva. Eksperimentalna istraživanja in vivo vršena su na maksilarnim molarima pasa. Nakon isteka perioda od 12 meseci životinje su žrtvovane, svi zdravi molari izvađeni i nastavljeno je ispitivanje kristalne strukture gleđnog tkiva in vitro.

Korišćena je metoda difrakcije X zrakova koja u okviru kristalografskih analiza jedino ima toliku osetljivost da se mogu uočiti i najmanje promene u dimenziji kristalne rešetke gleđnog tkiva tretiranog vodenim rastvorom organskog spinskog markera 4-Amono - Tempo

$\mathrm{Na}$ osnovu rezultata obavljenih istraživanja zaključeno je da organski molekuli, pored procesa difuzije kroz interprizmatične prostore gleđnog tkiva, igraju presudnu ulogu i u promenama dimenzija kristalne rešetke zbog vezivanja organskih delova molekula u strukturi kristala gleđi. Permanentne oscilacije broja difundovanih molekula markera u gleđi, ukazuju na proces njihovog vezivanja za strukturu gleđi koja na svakih nekoliko nedelja predstavlja supstituciju i resupstituciju $\mathrm{OH}$ jona iz kristalne rešetke gleđi sa organskim, neorganskim ili česticama iz nekih lokalno aplikovanih dentalnih materijala. Lokalno aplikovani preparati na bazi fluora moraju se svaka 2 meseca ponovo postavljati na gleđno tkivo stalnih zuba zbog resupstitucije i izlaska jona fluora iz kristalne rešetke apatita. 